\title{
EFEK PENAMBAHAN TERAPI PULSED ULTRASOUND (US) LOW INTENSITY \\ PADA LATIHAN KINESIOTHERAPY TERHADAP GAMBARAN C-REACTIVE PROTEIN (CRP) PADA KASUS OSTEOARTHRITIS (OA) GENU DI RSUD dr. DRADJAT PRAWIRANEGARA KABUPATEN SERANG
}

\author{
Dady Iskandar ${ }^{1}$, Susy Purnawati ${ }^{2}$, Muhammad Ali Imron ${ }^{3}$, Desak Made Wihandani ${ }^{4}$, \\ Ida Sri Iswari ${ }^{5}$, I Dewa Putu Sutjana ${ }^{6}$ \\ ${ }^{1}$ Program Studi Magister Fisiologi Keolahragaan Universitas Udayana, Denpasar \\ ${ }^{2,4,6}$ Fakultas Kedokteran Universitas Udayana, Denpasar \\ ${ }^{3}$ Fakultas Fisioterapi Universitas 'Aisyiyah, Yogyakarta \\ ${ }^{5}$ KSM Mikrobiologi Klinik, RSUP Sanglah, Denpasar \\ E-mail: dadyiskandar_81@yahoo.co.id
}

\begin{abstract}
ABSTRAK
Pendahuluan: Kemajuan pengetahuan tentang biologi molekuler pada tahun 90-an, mengubah paradigma mengenai patogenesis OA genu yang penyebabnya multifaktorial, diawali dengan munculnya mediator inflamasi dan bukan proses degeneratif semata. Tujuan Penelitian: Menganilisis perbedaan gambaran CRP pada pasien OA genu setelah mendapatkan penambahan terapi pulsed Ultrasound (US) low intensity pada latihan kinesiotherapy dibandingkan setelah mendapatkan latihan kinesiotherapy. Metode: Penelitian ini menggunakan rancangan true experimental, dengan pretest-posttest control group design. Jumlah responden sebanyak 26 orang pasien yang terdiagnosa OA genu yang datang ke poliklinik Fisioterapi RSUD dr. Dradjat Prawiranegara Kabupaten Serang yang disesuaikan dengan kriteria inklusi. Responden dibagi kedalam dua kelompok yang dipilih dengan random alokasi. Kelompok pertama terdiri dari 13 orang diberi latihan kinesiotherapy disebut Kelompok Kontrol. Kelompok kedua terdiri dari 13 orang diberi penambahan terapi pulsed Ultrasound (US) low intensity pada latihan kinesiotherapy disebut dengan Kelompok Perlakuan. Pemeriksaan CRP menggunakan metode imunoturbidimetri dari plasma darah dengan antikoagulan heparin. Hasil: (1) terdapat perbedaan gambaran CRP yang bermakna pada pasien OA genu setelah mendapatkan latihan kinesiotherapy (Kelompok Kontrol) dari rerata $0,35 \pm 0,28 \mathrm{mg} / \mathrm{dL}$ menjadi $0,19 \pm 0,15 \mathrm{mg} / \mathrm{dL}$ dengan nilai $p<0,05$; (2) terdapat perbedaan gambaran CRP yang bermakna pada pasien OA genu setelah mendapatkan penambahan terapi pulsed Ultrasound (US) low intensity pada latihan kinesiotherapy (Kelompok Perlakuan) dari rerata $0,75 \pm 0,53 \mathrm{mg} / \mathrm{dL}$ menjadi $0,44 \pm 0,33 \mathrm{mg} / \mathrm{dL}$ dengan nilai $p<0,05$; (3) terdapat perbedaan gambaran CRP yang bermakna pada pasien OA genu setelah mendapatkan penambahan terapi pulsed Ultrasound (US) low intensity pada latihan kinesiotherapy dibandingkan dengan setelah mendapatkan latihan kinesiotherapy dengan nilai $p<0,05$.
\end{abstract}

Kata kunci: kinesiotherapy, pulsed Ultrasound (US) low intensity, C-Reactive Protein (CRP), Osteoarthritis (OA) genu. 


\title{
THE EFFECT OF ADDITION \\ PULSED ULTRASOUND (US) THERAPY LOW INTENSITY \\ IN KINESIOTHERAPY EXERCISE \\ ON C-REACTIVE PROTEIN (CRP) DESCRIPTION IN OSTEOARTHRITIS (OA) GENU CASE \\ AT RSUD dr. DRADJAT PRAWIRANEGARA SERANG DISTRICT
}

\begin{abstract}
Background: The advancement of knowledge about molecular biology in the 90s changed the paradigm regarding the pathogenesis of Osteoarthritis (OA) genu which caused multifactorial causes, begining with the emergence of inflammatory mediators and not merely degenerative processes. Purpose: To Analyze the differences in CRP description in OA genu patients after receiving additional low intensity pulsed Ultrasound (US) therapy in kinesiotherapy exercise compared to after receiving kinesiotherapy exercise. Method: This study is true experimental, using the pretest-posttest control group design. The number of respondents was 26 patients who had been diagnosed with OA genu who came to the Physiotherapy clinic at RSUD dr. Dradjat Prawiranegara Serang District which is adjusted to the inclusion criteria. Respondents were divided into two groups selected by random alocation. The first group consisted of 13 people given the kinesiotherapy exercise and referred to the control group. The second group consisted of 13 people given an addition of low intensity pulsed Ultrasound (US) therapy in kinesiotherapy exercise and referred to the treatment group. CRP examination uses the immunoturbidimetry method of blood plasma with heparin anticoagulation. Result: (1) there was a significant difference in the CRP description in OA genu patients after receiving the kinesiotherapy exercise (control group) average from $0.35 \pm 0.28 \mathrm{mg} / \mathrm{dL}$ to be $0.19 \pm 0.15 \mathrm{mg} / \mathrm{dL}$ with a value of $p<0.05$; (2) there was a significant difference in the CRP description in OA genu patients after receiving an addition of low intensity pulsed Ultrasound (US) therapy in kinesiotherapy exercise (treatment group) average from $0.75 \pm 0.53 \mathrm{mg} / \mathrm{dL}$ to be $0.44 \pm 0.33 \mathrm{mg} / \mathrm{dL}$ with a value of $p<0.05$; (3) there was difference CRP description in OA genu patients between those who received an addition of low intensity pulsed Ultrasound (US) therapy in kinesiotherapy exercise those who received a kinesiotherapy exercise with a value of $p<0.05$.
\end{abstract}

Keywords: kinesiotherapy, low intensity pulsed Ultrasound (US), C-Reactive Protein (CRP), Osteoarthritis (OA) genu.

\section{PENDAHULUAN}

Kemajuan pengetahuan tentang biologi molekuler di era 90-an memunculkan teori dan karakteristik yang baru. Penemuan banyaknya mediator terlarut seperti sitokin pro-inflamasi atau prostaglandin pada cairan sinovial, yang mampu meningkatkan produksi Matriks Metalloproteinase (MMP) sebagai mediator utama degradasi kolagen oleh kondrosit, merupakan indikasi awal dari teori inflamasi. Hal inilah yang mengubah paradigma patogenesis Osteoarthritis (OA) yang sudah bertahan beberapa dekade dan menjadi perdebatan hingga saat ini ${ }^{1}$.

Pada mulanya OA dianggap sebagai penyakit degeneratif / penuaan yang ditandai dengan menipis hingga hilangnya tulang rawan. Data eksperimen terbaru menunjukkan bahwa tulang subchondral yang berperan sebagai 
peredam mekanik ternyata menjadi sumber mediator proses inflamasi serta terlibat dalam proses terjadinya nyeri dan degradasi lapisan dalam tulang rawan pada OA genu ${ }^{2}$.

Progresivitas OA berkembang perlahan selama 10 s.d 15 tahun dan umumnya menjadi simptomatik dan didapati adanya perubahan struktur sendi pada hasil radiografi setelah usia penderita menginjak 50 tahun. Itu artinya, perkembangan OA dimulai lebih awal dari yang diperkirakan dan hal ini diperkuat oleh data yang diperoleh dari Global Burden of Disease tahun 2015 yang menunjukkan bahwa OA menjadi penyakit urutan 20 teratas di dunia pada kelompok usia $40-45$ tahun $^{3}$.

Penggunaan agen farmakologis pada kasus ini harus melalui pertimbangan dengan menilai rasio resiko dan manfaat dari obat yang diresepkan secara hati-hati. Karena dari banyak obat-obatan yang direkomendasikan, selain menunjukkan karakteristik perawatan yang tidak ideal, munculnya efek samping pada tingkat sistemik dan lokal dapat menjadi resiko akibat obat yang diberikan ${ }^{4}$.

Kombinasi farmakologis dan nonfarmakologis menjadi skenario terapeutik yang ideal untuk kasus OA. Exercise menjadi pendekatan konservatif lainnya yang efektif, walaupun keefektifan jangka panjangnya, dosis optimal serta modalitas yang spesifik masih perlu diklarifikasi ${ }^{4}$.

Salah satu latihan yang dapat memberikan efek terapeutik dalam menurunkan level sitokin terkait dalam cairan sinovial dan menghambat degradasi tulang rawan yang diperantarai oleh faktor inflamasi pada OA genu adalah kinesiotherapy ${ }^{5}$. Program ini terdiri dari pemanasan, latihan penguatan (strengthening) otot (isotonik dan isometrik) secara manual dan dengan menggunakan thera-band, serta stretching dari otot ekstremitas bawah ${ }^{6}$.

Modalitas fisioterapi lainnya yang dipercaya mampu memberikan efek yang positif, non-invasif, dapat diulang dengan mudah dan tidak memiliki efek samping pada pasien OA genu adalah terapi Ultrasound (US). Mekanisme terapi US di sendi lutut digambarkan sebagai penerapan gelombang suara berfrekuensi tinggi yang menyebabkan efek thermal dan non-thermal yang pada gilirannya mengakibatkan peningkatan aliran darah dan aktivitas metabolik, penurunan respons inflamasi serta penurunan nyeri ${ }^{7}$.

C-Reactive Protein (CRP) merupakan protein pentamerik yang ditemukan dalam plasma darah yang berhubungan dengan peradangan. CRP diproduksi oleh hepatosit dimana sumber utama reaktan fase akut ini diatur oleh sitokin proinflamasi Interleukin-6 (IL-6) dan IL-1 yang berperan dalam patofisiologi OA dan secara klinis dapat dijadikan biomarker terkait $\mathrm{OA}^{8}$.

Dengan mempertimbangkan sebuah pengetahuan baru tentang proses patogenesis dari OA genu, maka relevan untuk secara klinis menganalisis efek dari latihan kinesiotherapy dan terapi pulsed US terhadap salah satu biomarker peradangan OA genu yaitu $C$ Reactive Protein (CRP) yang mampu mengendalikan inflamasi lokal dan sistemik serta memiliki potensi untuk mencegah serta mengurangi beberapa ciri patologis OA sehingga progresivitas OA dapat diperlambat.

\section{METODE PENELITIAN}

Penelitian ini menggunakan rancangan true experimental, dengan randomized pretestposttest control group design yang dilakukan di poliklinik Fisioterapi RSUD dr. Dradjat Prawiranegara Kabupaten Serang dari bulan Oktober 2018 s.d April 2019. Responden merupakan pasien yang telah terdiagnosis OA genu oleh Dokter Penanggung Jawab Pasien (DPJP) yang tercatat pada rekam medik pasien dan dibagi ke dalam dua kelompok yang dipilih dengan random alokasi. Kelompok pertama terdiri dari 13 orang diberi latihan kinesiotherapy disebut Kelompok Kontrol. Kelompok kedua terdiri dari 13 orang diberi penambahan terapi pulsed Ultrasound (US) low intensity pada latihan kinesiotherapy disebut dengan Kelompok Perlakuan.

Pemeriksaan CRP menggunakan metode imunoturbidimetri dari plasma darah dengan antikoagulan heparin. Intervensi diberikan 
sebanyak dua belas kali dalam jangka waktu satu bulan.

\section{HASIL PENELITIAN}

\section{Karakteristik Subjek Penelitian}

Tabel 1

Data demografi subjek penelitian

\begin{tabular}{|c|c|c|c|}
\hline \multirow[t]{2}{*}{ Variabel } & \multicolumn{2}{|c|}{$\begin{array}{l}\text { Kelompok } \\
\text { Kontrol }\end{array}$} & $\begin{array}{l}\text { Kelompok } \\
\text { Perlakuan }\end{array}$ \\
\hline & $\mathrm{f}$ & $\%$ & f $\%$ \\
\hline \multicolumn{4}{|l|}{ Jenis kelamin } \\
\hline Pria & 3 & 23,1 & 323,1 \\
\hline Wanita & 10 & 76,9 & 1076,9 \\
\hline \multicolumn{4}{|l|}{ Usia (tahun) } \\
\hline Mean \pm SD & 53,77 & $\pm 12,53$ & $54,85 \pm 12,66$ \\
\hline
\end{tabular}

\section{Data Deskripsi CRP}

Tabel 2

Data deskripsi hasil pengukuran CRP

\begin{tabular}{|c|c|c|c|c|c|c|}
\hline & \multicolumn{3}{|c|}{$\begin{array}{l}\text { Kelompok Kontrol } \\
(\mathrm{n}=13)\end{array}$} & \multicolumn{3}{|c|}{$\begin{array}{l}\text { Kelompok Perlakuan } \\
\qquad(\mathrm{n}=13)\end{array}$} \\
\hline & Min & $\operatorname{Max}$ & $\overline{\text { Mean } \pm \mathrm{SD}}$ & Min & $\operatorname{Max}$ & Mean \pm SD \\
\hline \multicolumn{7}{|c|}{ CRP $(\mathrm{mg} / \mathrm{dL})$} \\
\hline Pre & 0,06 & 1,02 & $0,35 \pm 0,28$ & 0,02 & 1,74 & $0,75 \pm 0,53$ \\
\hline Post & 0,04 & 0,45 & $0,19 \pm 0,15$ & 0,02 & 1,32 & $0,44 \pm 0,33$ \\
\hline Selisih & 0,00 & 0,89 & $0,16 \pm 0,24$ & $-0,06$ & 0,87 & $0,30 \pm 0,32$ \\
\hline
\end{tabular}

Tampak pada Tabel 2 bahwa rentang selisih minimal pada Kelompok Perlakuan sebesar -0,06 $\mathrm{mg} / \mathrm{dL}$ dan maksimal 0,87 $\mathrm{mg} / \mathrm{dL}$. Ini disebabkan karena nilai CRP setelah intervensi salah satu responden Kelompok Perlakuan lebih tinggi dibanding sebelum intervensi.

\section{Uji Normalitas dan Homogenitas}

Tabel 3

Hasil uji normalitas dan homogenitas

\begin{tabular}{|c|c|c|c|c|c|c|}
\hline \multirow{3}{*}{ Kelompok } & \multicolumn{3}{|c|}{ Shapiro Wilk Test* } & \multicolumn{3}{|c|}{ Levene's Test** } \\
\hline & \multicolumn{3}{|c|}{$p$} & \multicolumn{3}{|c|}{$p$} \\
\hline & Pre & Post & Selisih & Pre & Post & Selisih \\
\hline Kontrol & 0,082 & 0,010 & 0,001 & \multirow{2}{*}{0,047} & \multirow{2}{*}{0,114} & \multirow{2}{*}{0,074} \\
\hline Perlakuan & 0,283 & 0,055 & 0,064 & & & \\
\hline
\end{tabular}

Berdasarkan hasil yang disajikan pada Tabel 3 di atas, hanya nilai $p$ post intervensi dan selisih Kelompok Kontrol dengan nilai $p<0,05$ yang berarti tidak berdistribusi normal dan tidak homogen. Sedangkan untuk nilai $p$ lainnya berdistribusi normal dan varian data homogen.

Berdasarkan hasil analisis tersebut maka uji hipotesis I menggunakan uji nonparametrik yaitu Wilcoxon Signed Rank Test, uji hipotesis II menggunakan uji parametrik yaitu Paired Sample t Test dan uji statistik hipotesis III menggunakan uji nonparametrik yaitu Mann Whitney U Test.

\section{Uji Beda CRP Pada Masing-masing Kelompok dan Antar Kelompok}

Hasil analisis dari uji beda hipotesis I, II dan III disajikan pada Tabel 4 di bawah ini:

Tabel 4

Hasil uji beda kedua kelompok

\begin{tabular}{cccc}
\hline \multirow{2}{*}{ Intervensi } & \multicolumn{2}{c}{$\begin{array}{c}\text { Mean } \pm \text { SD } \\
(\mathrm{mg} / \mathrm{dL})\end{array}$} & Nilai \\
\cline { 2 - 3 } & Pre & Post & $p$ \\
\hline Latihan kinesiotherapy & $0,35 \pm 0,28$ & $0,19 \pm 0,15$ & 0,002 \\
$\begin{array}{c}\text { Latihan kinesiotherapy }+ \\
\text { pulsed Ultrasound (US) } \\
\text { low intensity } \\
\text { Nilai } p\end{array}$ & $0,75 \pm 0,53$ & $0,44 \pm 0,33$ & 0,005 \\
\hline
\end{tabular}

Berdasarkan Tabel 4 di atas, tampak bahwa pada Kelompok Kontrol ditemukan perbedaan gambaran CRP yang bermakna pada pasien OA genu setelah latihan kinesiotherapy diberikan sebanyak dua belas kali selama satu bulan dengan nilai $p<0,05$.

Pada Kelompok Perlakuan ditemukan perbedaan gambaran CRP yang bermakna pada pasien OA genu setelah diberikan penambahan terapi pulsed Ultrasound (US) low intensity pada latihan kinesiotherapy sebanyak dua belas kali terapi selama satu bulan dengan nilai $p<0,05$.

Pada uji beda rerata data setelah intervensi pada ke dua kelompok ditemukan 
perbedaan gambaran CRP yang bermakna pada pasien OA genu setelah mendapatkan penambahan terapi pulsed Ultrasound (US) low intensity pada latihan kinesiotherapy dibandingkan dengan setelah mendapatkan latihan kinesiotherapy antara yang dengan nilai $p<0,05$.

\section{PEMBAHASAN}

\section{C-Reactive Protein (CRP) dan Efek Latihan Kinesiotherapy}

Temuan dari penelitian ini adalah terdapat perbedaan gambaran CRP yang bermakna pada pasien OA genu di RSUD dr. Dradjat Prawiranegara Kabupaten Serang setelah mendapatkan latihan kinesiotherapy.

Data hasil pengukuran CRP awal sebelum diberikan latihan kinesiotherapy dan dijadikan sebagai data baseline pada Kelompok Kontrol, menunjukkan $0,35 \pm 0,28 \mathrm{mg} / \mathrm{dL}$ dan setelah diberikan intervensi tersebut sebanyak 12 kali selama satu bulan menjadi $0,19 \pm 0,15 \mathrm{mg} / \mathrm{dL}$.

Hasil penelitian yang serupa yang dilakukan oleh Shao-Lan, et al. (2013) dengan data baseline CRP $11,33 \pm 0,90 \mu \mathrm{g} / \mathrm{ml}$ dan setelah mendapatkan latihan kinesiotherapy selama empat minggu berubah menjadi $6,01 \pm 1,13 \mu \mathrm{g} / \mathrm{ml}$ menyimpulkan bahwa latihan kinesiotherapy mengurangi CRP pada pasien OA genu?

Beberapa mekanisme potensial yang dapat mengurangi peradangan kronis yang terjadi jika latihan kinesiotherapy dilakukan secara teratur, di antaranya adalah terjadinya peningkatan produksi dan sekresi sitokin anti-inflamasi yang berasal dari otot yang berkontraksi serta adaptasi di generasi intraseluler dari Reactive Oxygen Species (ROS) ${ }^{10}$.

Selama latihan berlangsung, glikogen intramuskuler yang sudah ada sebelum latihan menjadi stimulus penting terjadinya transkripsi gen IL-6. Kenaikkan sementara IL-6 yang berasal dari kontraksi otot skletal, menginduksi produksi sitokin anti-inflamasi seperti IL-1 Receptor Antagonist (IL-1RA) dan IL-10 terlarut, dimana ke dua sitokin ini bertindak sebagai antagonis dari sitokin pro-inflamasi seperti IL-1 $\beta$ dan TNF- $\alpha$. IL-6 juga merangsang terjadinya pelepasan kortisol dimana kortisol merupakan hormon anti-inflamasi ${ }^{10}$.

Inter Leukin-6 juga menjadi sensor energi yang menginduksi beberapa efek metabolisme, di antaranya lipolisis dan oksidasi lemak yang terlibat dalam homoestasis glukosa selama latihan. Karena latihan merupakan akumulasi dari banyak latihan-latihan akut, maka peningkatan yang terjadi pada IL-6 dapat berkontribusi dalam pengurangan peradangan kronis jangka panjang ${ }^{11}$.

Selain proses tersebut, efek anti-inflamasi dari latihan kinesitherapi juga dapat timbul akibat hasil dari jalur / pathway modulasi sinyal intraseluler yang distimulasi oleh Nitric Oxide (NO) dan ROS. Selama latihan berlangsung, peningkatan produksi NO dan ROS berperan penting untuk mendorong mekanisme pertahanan anti-inflamasi. Respon adaptif dari jalur redoks melindungi otot rangka dari paparan peningkatan ROS setelah latihan. Selain itu, konsentrasi TNFa pada otot rangka akan dirubah oleh ROS sehingga mampu mengurangi reaksi peradangan ${ }^{12}$.

\section{C-Reactive Protein (CRP) dan Efek Penambahan terapi Pulsed Utrasound (US) Low Intensity Pada Latihan Kinesiotherapy}

Temuan dari penelitian ini adalah terdapat perbedaan gambaran CRP yang bermakna pada pasien OA genu di RSUD dr. Dradjat Prawiranegara Kabupaten Serang setelah mendapatkan penambahan terapi pulsed Utrasound (US) low intensity pada latihan kinesiotherapy.

Data hasil pengukuran CRP awal sebelum diberikan penambahan terapi pulsed Utrasound (US) low intensity pada latihan kinesiotherapy dan dijadikan sebagai data baseline pada Kelompok Perlakuan, menunjukkan 0,75 $\pm 0,53$ $\mathrm{mg} / \mathrm{dL}$ dan setelah diberikan intervensi tersebut sebanyak dua belas kali selama satu bulan menjadi $0,44 \pm 0,33 \mathrm{mg} / \mathrm{dL}$. Begitupun dengan data pada Kelompok Perlakuan, data tersebut 
tidak hanya melibatkan responden dengan hasil pengukuran CRP yang tinggi.

Hasil penelitian sebelumnya yang dilakukan oleh Kiraly, et al. (2017) menunjukkan bahwa terapi pulsed Utrasound (US) low intensity pada pasien Rheumatoid Arthritis (RA) dengan teknik underwater, memberikan hasil yang positif terhadap penurunan CRP. Data baseline CRP menunjukkan 11,12 $\pm 9,38 \mathrm{mg} / \mathrm{l}$ dan mengalami penurunan menjadi 7,49 $\pm 9,85 \mathrm{mg} / \mathrm{l}$ setelah intervensi sebanyak 10 kali selama dua minggu $^{13}$. Walaupun secara fundamental inflamasi pada OA dan RA berbeda, namun secara umum inflamasi keduanya termasuk kedalam golongan low grade yang kronis, yang salah satu biomarker-nya adalah $\mathrm{CRP}^{14}$.

Secara klinis, efek termal dan mekanik dari penambahan terapi pulsed Utrasound (US) low intensity menjadi efek anti-inflamasi yang diduga terjadi akibat vasodilatasi. Selain itu terapi pulsed Utrasound (US) low intensity juga mampu memberikan efek peningkatan fungsi endotel pada manusia yang memiliki efek vaskular anti-inflamasi, serta terjadinya peningkatan produksi nitrogen-monoxid. Efek vaskular dari penambahan terapi ini yaitu dengan menghambat agregasi trombosit dan adhesi leukosit, menekan proliferasi sel otot polos dan merangsang terjadinya angiogenesis dan perbaikan jaringan ${ }^{15}$.

Selain itu, terapi pulsed Utrasound (US) low intensity juga berperan positif pada sinovium yang mengalami inflamasi. Dalam kondisi sinovitis tubuh akan merekrut neutrofil dalam jumlah besar masuk ke dalam sinovium. Kemudian neutrofil akan mengeluarkan butiranbutiran yang bertugas untuk menghilangkan mikroba dan jaringan yang terinfeksi. Neutrofil yang mati akibat apoptosis atau Neutrophil Extracellular Traps (NET)osis, akan mengaktifkan makrofag untuk melakukan tugasnya dalam proses pembersihan NETosis. Namun jika pembersihan NETosis terjadi kelambatan maka akan menyebabkan peradangan yang berkepanjangan ${ }^{16}$.

Pada kondisi tesebut pemberian pulsed Utrasound (US) low intensity mampu meningkatkan proses pembersihan NETosis dengan cara meningkatkan fagositosis makrofag, dan proses inilah yang mendasari efek terapi pulsed Utrasound (US) low intensity pada sinovium yang mengalami arthritis ${ }^{16}$. Selain itu efek terapeutik dari terapi ini diyakini mampu mengurangi proses inflamasi lainnya yang berkaitan, salah satunya adalah adanya perubahan CRP yang berkontribusi pada progresivitas penyakit OA genu.

\section{Perbandingan Efek Penambahan Terapi Pulsed Ultrasound (US) Low Intensity Pada Latihan Kinesiotherapy dan Intervensi Latihan Kinesiotherapy Terhadap Gambaran CRP}

Temuan dari penelitian ini adalah terdapat perbedaan gambaran CRP yang bermakna pada pasien OA genu di RSUD dr. Dradjat Prawiranegara Kabupaten Serang setelah mendapatkan penambahan terapi pulsed Utrasound (US) low intensity pada latihan kinesiotherapy dibandingkan setelah mendapatkan latihan kinesiotherapy.

Hasil analisis uji beda rerata data menunjukkan $0,19 \pm 0,15 \quad \mathrm{mg} / \mathrm{dL} \quad$ setelah mendapatkan latihan kinesiotherapy dan $0,44 \pm 0,33 \mathrm{mg} / \mathrm{dL}$ setelah mendapatkan penambahan terapi pulsed Utrasound (US) low intensity pada latihan kinesiotherapy.

Hasil analisis tersebut menunjukkan bahwa rerata data setelah penambahan terapi pulsed Ultrasound (US) low intensity pada latihan kinesiotherapy memiliki nilai yang menunjukkan adanya perbedaan gambaran CRP yang bermakna bila dibandingkan dengan nilai rerata data setelah latihan kineshiterapy. Namun hasil ini tidak dapat disimpulkan bahwa penambahan terapi pulsed Ultrasound (US) low intensity pada latihan kinesiotherapy memberikan penurunan yang bermakna terhadap gambaran CRP pada pasien OA genu dikarenakan melibatkan responden dengan CRP pada rentang $0,02 \mathrm{mg} / \mathrm{dL}$ sampai dengan 1,74 $\mathrm{mg} / \mathrm{dL}$.

Adanya perbedaan gambaran CRP yang bermakna setelah intervensi pada kedua 
kelompok terjadi karena selain pemberian latihan kinesiotherapy memberikan efek bermakna terhadap gambaran CRP, penambahan terapi pulsed Ultrasound (US) low intensity juga memberikan efek bermakna terhadap gambaran CRP.

Secara umum efek yang yang terjadi dimulai setelah gelombang ultrasonik menembus jaringan target yang menyebabkan pergerakan cairan dan makromolekuler pada membran sel lokal. Hal ini akan menghasilkan stimulasi mekanis yang kemudian mengubah sifat fisik dan bilogis sel, seperti permeabilitas membran sel, pergerakan cairan dan pertukaran ion intraseluler, meningkatnya aktivitas anabolik, menurunkan tingkat aktivitas katabolik serta mencegah apoptosis pada kondrosit, yang pada akhirnya semuanya mengubah metabolisme dan pertumbuhan sel ${ }^{17}$.

Pengaruh energi thermal dan non-thermal (mekanikal) yang ditimbulkan dari terapi pulsed Utrasound (US) low intensity mampu memberikan efek biofisik yang bermanfaat untuk penurunan inflamasi lokal yang berkorelasi dengan perubahan gambaran CRP pada OA genu.

Terapi pulsed Utrasound (US) low intensity digunakan untuk menstimulasi proliferasi sel dan perbaikan jaringan dimana berkorelasi dengan perubahan gambaran CRP. Dimulai dengan terjadinya efek vaskular anti-inflamasi sebagai akibat thermal effect yang menyebabkan vasodilatasi sehingga aliran darah menjadi lancar, dan pada akhirnya menstimulasi terjadinya angiogenesis yang mengawali proses perbaikan jaringan ${ }^{15}$.

Perubahan kepadatan $\mathrm{Ca}^{2+}$ ekstrasel sehingga menstimulasi peningkatan fosforilasi protein berdasarkan sinyal sel yang diinfiltrasi melalui mechanoreceptors yang reseptornya berlokasi pada periosteum, juga ditemukan sebagai efek pemberian terapi pulsed Utrasound (US) low intensity, dan mekanisme tersebut mampu mempengaruhi proliferasi reaksi inflamasi sel-sel tulang rawan dan sekaligus mempengaruhi konsentrasi CRP dalam darah ${ }^{18}$.

Adanya perbaikan inflamasi lokal juga sangat berpengaruh terhadap perubahan gambaran CRP. Meningkatnya proses pembersihan NETosis dengan cara meningkatkan fagositosis makrofag pada sinovium yang mengalami arthritis juga merupakan salah satu efek pemberian terapi pulsed Utrasound (US) low intensity. Penurunan aktivitas inflamasi ini, akan berakibat pada penurunan produksi sitokin pro-inflamasi sepert IL-6 di sinovium, yang pada akhirnya akan berpengaruh pada pengurangan produksi CRP di organ hati yang salah satu stimulusnya adalah produksi IL-6 yang berlebih ${ }^{16}$.

Ketika latihan kinesiotherapy dikombinasikan dengan pulsed Utrasound (US) low intensity maka yang akan terjadi adalah adanya mekanisme gabungan antara proses pengurangan respon inflamasi lokal, sebagai efek thermal dan non-thermal dari pemberian terapi pulsed Utrasound (US) low intensity, serta proses pengurangan peradangan sistemik kronis dalam jangka yang panjang, sebagai efek dari peningkatan sementara IL-6 yang berpengaruh pada terjadinya peningkatan sitokin anti-inflamasi.

Jika dibandingkan dengan latihan kinesiotherapy yang tanpa diberikan terapi pulsed Utrasound (US) low intensity, proses perubahan akibat efek themal dan non-thermal dari pulsed Utrasound (US) low intensity tidak didapat. Tidak adanya perbaikan inflamasi lokal yang berkorelasi dengan perubahan gambaran CRP secara sistemik menyebabkan pada Kelompok Kontrol perbedaan gambaran CRPnya lebih sedikit setelah diberikan intervensi tersebut.

\section{KETERBATASAN PENELITIAN}

Tidak mencantumkan CRP yang tinggi pada kriteria inklusi. Sehingga data yang diperoleh tidak hanya melibatkan responden dengan hasil pengukuran CRP yang tinggi. Kondisi ini disebabkan karena regulasi atau alur dalam penerimaan pasien (calon responden) di poliklinik Fisioterapi RSUD dr. Dradjat Prawiranegara Kabupaten Serang mengharuskan 
mendapatkan rujukan terlebih dahulu dari Dokter Penanggung Jawab Pasien (DPJP) dari poliklinik terkait. Dengan demikian, kemungkinan responden mengkonsumsi obat anti inflamasi tidak dapat diabaikan.

\section{SIMPULAN}

1. Ditemukan perbedaan yang bermakna pada gambaran $C$-Reactive Protein (CRP) setelah latihan kinesiotherapy pada pasien OA genu di RSUD dr. Dradjat Prawiranegara Kabupaten Serang.

2. Ditemukan perbedaan yang bermakna pada gambaran $C$-Reactive Protein (CRP) antara setelah penambahan terapi pulsed Ultrasound (US) low intensity pada latihan kinesiotherapy untuk pasien OA genu di RSUD dr. Dradjat Prawiranegara Kabupaten Serang.

3. Ditemukan perbedaan gambaran $C$-Reactive Protein (CRP) yang bermakna pada pasien OA genu di RSUD dr. Dradjat Prawiranegara Kabupaten Serang setelah mendapatkan penambahan terapi pulsed Ultrasound (US) low intensity pada latihan kinesiotherapy dibandingkan setelah mendapatkan latihan kinesiotherapy.

\section{DAFTAR PUSTAKA}

1. Berenbaum, F. 2012. Osteoarthritis as an inflammatory disease (osteoarthritis is not osteoarthrosis!). Osteoarthritis and cartilage, 21: 16-21.

2. Loeser, R.F., Goldring, S.R., Scanzello, C.R., Goldring, M.B. 2012. Osteoarthritis, A Disease of the Joint as an Organ. Arthritis \& Rheumatism, Vol. 64, No. 64, p. 1697-707.

3. Loeser, R.F. 2013. Aging Processes and the Development of Osteoarthritis. Curr Opin Rheumatol, 25(1): 108-13.

4. Kon, E., Filardo, G., Drobnic, M., Madry, H., Jelic, M., Van Dijk, N., Villa, S.D. 2012. Non-surgical management of early knee osteoarthritis. Knee Surg Sports Traumatol Arthrosc, 20: 436-49.
5. Shao-Lan, Z., Hong-Qi, L., Xiao-Zu, X., Juan, Z., Jiao-Jiao, G., Jin, C. 2013. Effects of exercise therapy on knee joint function and synovial fluid cytokine levels in patients with knee osteoarthritis. Molecular Medicine Reports, 7: 183-6.

6. Maggioni, M.A., Ce', E., Rampichini, S., Ferrario, M., Giordano, G., Veicsteinas, A., Merati, G. 2010. Electrical stimulation versus kinesiotherapy in improving functional fitness in older women: A randomized controlled trial. Archives of Gerontology and Geriatrics, 50: e19-e25.

7. Ulus, Y., Tander, B., Akyol, Y., et al. 2012. Terapeutic ultrasound versus sham ultrasound for the management of patients with knee osteoarthritis: A randomized double-blind controlled clinical study. International Journal of Rheumatic Diseases, Vol. 15, No. 2, p. 197-206.

8. Alina, C., Stout, Barbe, M.F., Eaton, C.B., Amin, M., Al-Eid, F., Price, L.L., Lu, B., Lo, G.H., Zhang, M., Pang, J., McAlindon, T.E., Driban, J.B. 2018. Inflammation and glucose homeostasis are associated with specific structural features among adults without knee osteoarthritis: a crosssectional study from the osteoarthritis initiative. BMC Musculoskeletal Disorders, 19: 1.

9. Shao-Lan, Z., Hong-Qi, L., Xiao-Zu, X., Juan, Z., Jiao-Jiao, G., Jin, C. 2013. Effects of exercise therapy on knee joint function and synovial fluid cytokine levels in patients with knee osteoarthritis. Molecular Medicine Reports, 7: 183-6.

10. Allen, J., Sun, Y., Woods J.A. 2015. Exercise and The Regulation of Inflammatory Respons. Progress in Moleculer Biology and Translation Science, Volume 135. ISSN: 1877-1173.

11. Petersen, A.M., Pedersen, B.K. 2006. The role of IL-6 in mediating the antiinflammatory effects of exercise. $J$ Physiol Pharmacol, 57(Suppl 10): 43-51.

12. Scheele, C., Nielsen, S., Pederson, B.K. 2009. ROS and Myokine Promote Muscle 
Adaptation to Exercise. Trends Endocrinol Metab, 20: 95-99.

13. Kiraly, M., Varga, Z., Szanvo, F., Kiss, R., Hodosi, K., Bender, T. 2017. Effects of underwater ultrasound therapy on pain, inflammation, hand function and quality of life in patients with rheumatoid arthritis - a randomized controlled trial. Braz J Phys Ther, 21(3): 199-205.

14. Robinson, W.H., Lepus, C.M., Wang, Q., Raghu, H., Mao, R., Lindstrom, T.M., Sokolove, J. 2016. Low-grade inflammation as a key mediator of the pathogenesis of osteoarthritis. Nat. Rev. Rheumatol,12(10): 580-592.

15. Cruz, J.M., Hauck, M., Cardoso Pereira A.P. 2016. Effects of different therapeutic ultrasound waveforms on endothelial function in healthy volunteers: a randomized clinical trial. Ultrasound Med Biol, 42(2):471-480.

16. Chung, J.I., Min, B.H., Baik, E.J. 2016. Effect of Continous-Wave Low Intensity Ultrasound in Inflammatory Resolution of Arthritis-Associated Synovitis. Phys Ther, 96: 808-817.

17. Leong, D.J., Zhang, H., Xu, L., Tang, J., Hirsh, D.M, et al.2013. Therapeutic Ultrasound: Osteoarthritis SymptomModification and Potential for Disease Modification, 2013;1(2): 5.

18. Kang, J.I., Kim, Y.N., Choi, H. 2014. Effects of Low-intensity Pulsed Ultrasound and Cryotherapy on Recovery of Joint Function and C-reactive Protein Levels in Patients after Total Knee Replacement Surgery. J. Phys. Ther. Sci, 26: 1033-6. 